\title{
The Alpine Mountain-Plain Circulation: Airborne Doppler Lidar Measurements and Numerical Simulations
}

\author{
M. WeISSMANN \\ Institute of Atmospheric Physics, DLR Oberpfaffenhofen, Wessling, Germany \\ F. J. BRAUN \\ Institute for Meteorology and Climate Research, Forschungszentrum Karlsruhe, Karlsruhe, Germany \\ L. GANTNER \\ Meteorological Institute, University of Munich, Munich, Germany \\ G. J. MAYR \\ Department of Meteorology and Geophysics, University of Innsbruck, Innsbruck, Austria \\ S. RAHM AND O. REITEBUCH \\ Institute of Atmospheric Physics, DLR Oberpfaffenhofen, Wessling, Germany
}

(Manuscript received 17 June 2004, in final form 9 February 2005)

\begin{abstract}
On summer days radiative heating of the Alps produces rising air above the mountains and a resulting inflow of air from the foreland. This leads to a horizontal transport of air from the foreland to the Alps, and a vertical transport from the boundary layer into the free troposphere above the mountains. The structure and the transports of this mountain-plain circulation in southern Germany ("Alpine pumping") were investigated using an airborne 2- $\mu \mathrm{m}$ scanning Doppler lidar, a wind-temperature radar, dropsondes, rawinsondes, and numerical models. The measurements were part of the Vertical Transport and Orography (VERTIKATOR) campaign in summer 2002. Comparisons of dropsonde and lidar data proved that the lidar is capable of measuring the wind direction and wind speed of this weak flow toward the Alps (1-4 $\mathrm{m} \mathrm{s}^{-1}$ ). The flow was up to $1500 \mathrm{~m}$ deep, and it extended $\sim 80 \mathrm{~km}$ into the Alpine foreland. Lidar data are volume measurements (horizontal resolution $\sim 5 \mathrm{~km}$, vertical resolution $100 \mathrm{~m}$ ). Therefore, they are ideal for the investigation of the flow structure and the comparison to numerical models. Even the vertical velocities measured by the lidar agreed with the mass budget calculations in terms of both sign and magnitude. The numerical simulations with the fifth-generation Pennsylvania State University-NCAR Mesoscale Model (MM5) (mesh size 2 and $6 \mathrm{~km}$ ) and the Local Model (LM) of the German Weather Service (mesh size 2.8 and $7 \mathrm{~km}$ ) reproduced the general flow structure and the mass fluxes toward the Alps within $86 \%-144 \%$ of the observations.
\end{abstract}

\section{Introduction}

One of the objectives of the German Vertical Transport and Orography (VERTIKATOR) project in summer 2002 (Lugauer et al. 2003) was to quantify the mass

Corresponding author address: Martin Weissmann, Deutsches Zentrum für Luft- und Raumfahrt (DLR), Institute of Atmospheric Physics, D-82230 Wessling, Germany.

E-mail: martin.weissmann@dlr.de flux from the Alpine foreland into the Alps on days with strong insolation, and to investigate whether this transport is properly represented in numerical models. The air within mountain areas is heated or cooled faster than over the plains because the air volume is smaller due to surrounding terrain (Steinacker 1984). Air over plateaus in the mountain massifs is also overheated relative to plains as it provides an elevated heating source. Consequently, the daily range of the mean temperature in valleys is nearly twice that over plains (Ver- 
geiner and Dreiseitl 1987). On sunny days this leads to a temperature difference between the foreland and the Alps with a resulting heat low in the mountains. The pressure gradient drives a wind from the foreland into the Alps. Additionally, the gradual height increase of the terrain from north to south drives a slope wind, which enhances the northerly flow.

The Alpine mountain-plain circulation is also called Alpine pumping ("Alpines pumpen" in German) because air from the foreland is "pumped" into the Alps (Lugauer and Winkler 2002). The strength of the flow is usually a few meters per second, and the flow extends up to $100 \mathrm{~km}$ out into the Alpine foreland (Corsmeier et al. 2003).

Similar flow systems exist in all mountain ranges of the world, and there are many studies on diurnal wind systems in various mountain ranges (e.g., Raymond and Wilkening 1980; Banta 1984; Reiter and Tang 1984; Egger 1987; Egger et al. 2000; Whiteman and Bian 1998). However, it has always been difficult to measure the mesoscale effects of mountains and the mass flux toward the mountains with conventional instruments. Advances in airborne lidar and other measurement technologies can provide new insights into these processes.

There are many sources of pollutants in the foreland to the north and south of the Alps including large cities such as Munich, Germany; Vienna, Austria; and Milan and Turin, Italy. Alpine pumping transports pollutants toward the Alps from both the north and south (Seibert et al. 1998; Wotawa et al. 2000; Nyeki et al. 2002). Over the mountains pollutants are then transported vertically from the boundary layer into the free troposphere in convective cells (Carnuth and Trickl 2000). Furthermore, the horizontal inflow converges above the mountains, frequently initiating the formation of thunderstorms (Cotton et al. 1983; Banta and Schaaf 1987; Schaaf et al. 1988). Later on, these storms, which are initiated over the mountains, are often advected over the plains by the large-scale flow.

The tropospheric counterflow of Alpine pumping is usually masked by stronger gradient winds, but it can be observed as a climatological divergence between rawinsondes to the north and south of the Alps (Burger and Ekhart 1937). The synoptic preconditions for Alpine pumping are strong incoming solar radiation and weak large-scale pressure gradients, so that synopticscale winds will not subsume the weak flow of Alpine pumping. These conditions are usually fulfilled when central Europe is under a high pressure area or ridge. Alpine pumping develops on about $30 \%$ of all days between April and September (Lugauer et al. 2003). It is most common in summer, but it also occurs in spring and fall. Only in winter is the phenomenon rare because of the weak incoming solar radiation and reflection of solar radiation by the snow cover.

This study provides an observational analysis of Alpine pumping on 19 July 2002 and compares it to a variety of numerical simulations with the fifthgeneration Pennsylvania State University-National Center for Atmosphere Research (Penn State-NCAR) Mesoscale Model (MM5) and the Local Model (LM) of the German Weather Service. The main intention was to evaluate the simulated mass fluxes toward the Alps quantitatively. The qualitative interpretation of the simulations is limited to the important flow features.

The region of southern Germany and western Austria was chosen as the investigation area (Fig. 1). The main Alpine crest with mountains of up to $3800 \mathrm{~m}$ MSL is located in the south of the investigation area [south of Innsbruck, Austria (IBK)] and several other mountain ranges (Karwendel, Wettersteingebirge, etc.) with mountains of 2000-3000 m MSL located north of IBK. The height of the plains north of the Alps gradually increases from about $400 \mathrm{~m}$ in the north of the investigation area to $700 \mathrm{~m}$ MSL in the vicinity of the Alps. The 19 July case is a typical case of Alpine pumping. A high pressure caused a sunny day in the investigation area with weak large-scale winds at all heights.

Data from the airborne Doppler lidar of the Deutsches Zentrum für Luft- und Raumfahrt (DLR) made it possible to investigate the three-dimensional structure of the circulation. The lidar measured wind cross sections parallel and perpendicular to the flow, mean profiles of the vertical velocity, and aerosol backscatter intensity. The location of the measurements is shown in Fig. 1. Additionally, data from a ground-based wind-temperature radar were used to study the temporal evolution of the flow. Five dropsondes and three rawinsondes provided profiles of temperature and humidity. Furthermore, the study derives the mass flux toward the Alps through two 200-km-long vertical cross sections parallel to the northern rim of the Alps.

The model setup and the airborne Doppler lidar system are described in the following parts of section 1. The synoptic situation and the temporal evolution of the circulation are discussed in section 2. Section 3 discusses the horizontal and vertical structure of Alpine pumping. Section 4 gives a quantitative evaluation of the numerical simulations. Section 5 discusses the vertical motions of the circulation, and the possibilities of measuring vertical velocities with an airborne Doppler lidar. Finally, the conclusions summarize the main results of the study. 


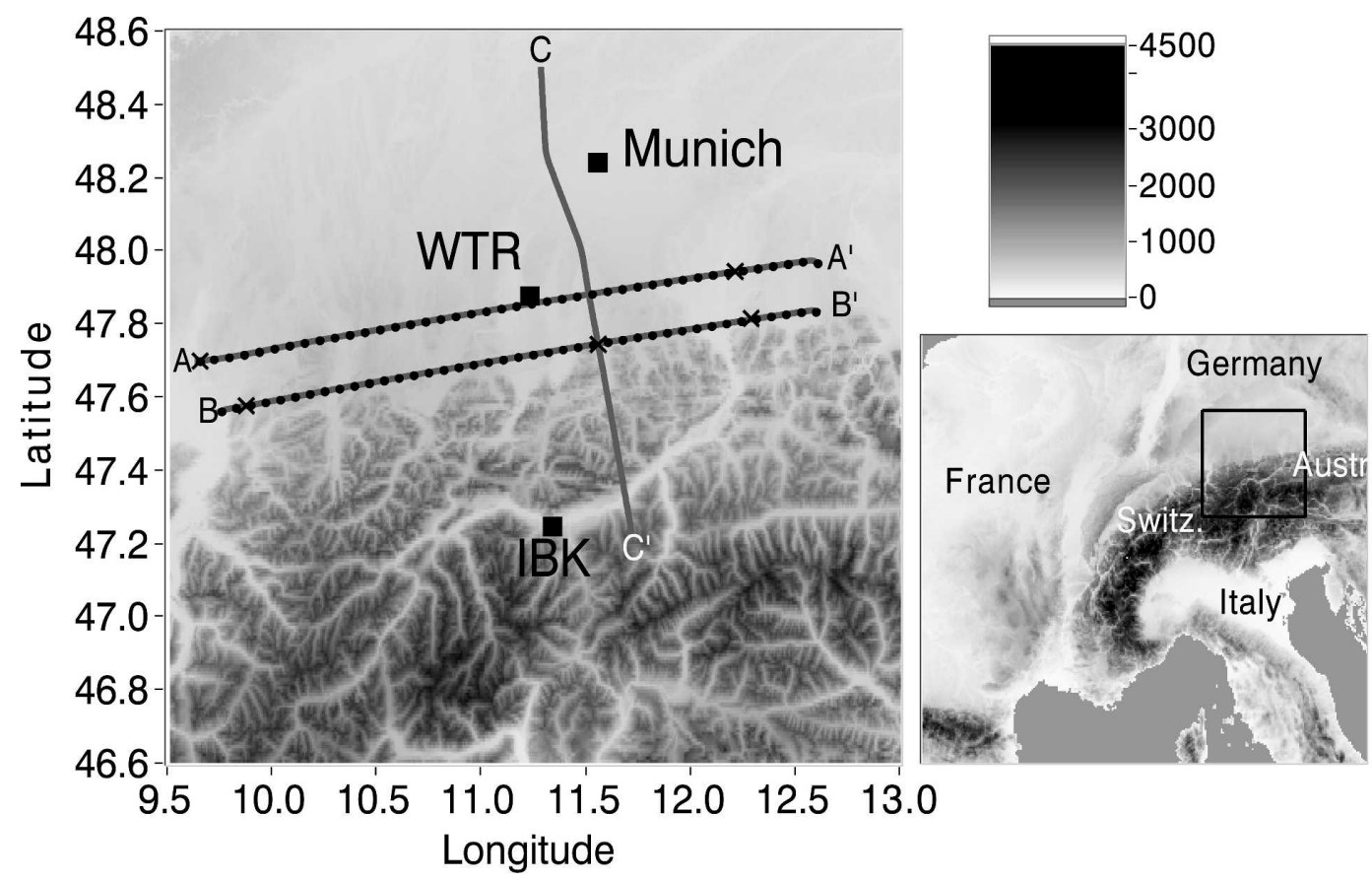

FIG. 1. (right) Map of central Europe with a black inset showing the location of the investigation area. (left) Topography of the investigation area with the location of Munich, Innsbruck (IBK), and the wind-temperature radar at Lichtenau (WTR). The position of the dropsondes is shown with black $\times$, and the position of the lidar cross sections $\left(\mathrm{AA}^{\prime}, \mathrm{BB}^{\prime}\right.$, and $\left.\mathrm{CC}^{\prime}\right)$ with gray lines. Black points indicate the individual profiles of the two west-east cross sections of lidar wind measurements $\left(\mathrm{AA}^{\prime}\right.$ and $\left.\mathrm{BB}^{\prime}\right)$.

\section{a. The airborne 2- $\mu m$ Doppler lidar system of $D L R$}

The Doppler lidar can be operated in a scanning mode or at a constant angle (Table 1). In the scanning mode the system measures profiles of three-dimensional wind vectors beneath the aircraft with a vertical and horizontal resolution of $100 \mathrm{~m}$ and about $5 \mathrm{~km}$, respectively. The profiles are obtained using the velocity-azimuth display (VAD) technique (Browning and Wexler 1968; Smalikho 2003) with a conical step and stare scan around the vertical axis with 24 positions (Rahm et al. 2003). The accumulation time is 1 or $2 \mathrm{~s}$ at every position. Combined with the movement of the aircraft this results in a cycloid scan pattern (Reitebuch et al. 2001). The use of airborne wind lidar to study mesoscale flow structures has already been shown in several studies using the $10-\mu \mathrm{m}$ wind infrared Doppler lidar (WIND) system (Reitebuch et al. 2003, 2004; Bastin et al. 2005). The 2- $\mu \mathrm{m}$ system has the advantage of a repetition rate of $500 \mathrm{~Hz}$ instead of the $10 \mathrm{~Hz}$ used for the WIND system. In consequence, 500 or 1000 pulses are accumulated at every position to reduce speckle noise. Furthermore, the $2-\mu \mathrm{m}$ laser has a near-Gaussian shape in the spatial, temporal, and spectral domains, which reduces the uncertainty of the Doppler esti-

mates. Over land a strong ground return is obtained that is used for the calibration of the aircraft attitude angles and speed since the velocity of the ground should equal zero.

For the calculation of the three-dimensional wind vector two different algorithms were used. The first one accumulates the spectra as described in Smalikho (2003), and the other one is a sine-fit algorithm. The lidar data were compared to five dropsondes that were

TABLE 1. System specifications of the pulsed 2- $\mu \mathrm{m}$ airborne Doppler lidar operated at DLR.

Development

Transmitter laser Wavelength energy Repetition rate Pulse length

Vertical resolution Telescope $\varnothing$

Power $\times$ aperture

Nadir angle

Operation

Accuracy of horizontal wind speed
DLR, Coherent Technologies, Inc. (CTI) photonics

Tm:LuAG

$2.02254 \mu \mathrm{m} 1.5 \mathrm{~mJ}$

$500 \mathrm{~Hz}$

$400 \mathrm{~ns}$ full-width half-maximum (FWHM)

$100 \mathrm{~m}$

$0.1 \mathrm{~m}$

$6 \mathrm{~mW} \mathrm{~m}^{-2}$

$20^{\circ}$

Conical scan or constant azimuth angle

$0.5-1.5 \mathrm{~m} \mathrm{~s}^{-1}$ 
launched on the same flight. One example of the comparison is shown in Fig. 2. With the accumulation algorithm the comparison of horizontal velocities showed a bias of $0.05 \mathrm{~m} \mathrm{~s}^{-1}$ and a standard deviation of $1.1 \mathrm{~m} \mathrm{~s}^{-1}$, and with the sine fit a bias of $0.09 \mathrm{~m} \mathrm{~s}^{-1}$ and a standard deviation of $1.2 \mathrm{~m} \mathrm{~s}^{-1}$. It must be noted that a part of the standard deviation is due to the horizontal variability of the wind field (representativeness, sampling error). The dropsonde data are a number of point measurements, while the lidar data are an average along the scan pattern of one scan revolution $(\sim 5 \mathrm{~km})$. This obviously leads to different measurements by the dropsondes and the lidar whenever the wind field is not homogeneous.

If the lidar is operated at a constant azimuth angle, the lidar only measures the wind component in the direction of the viewing angle (line-of-sight velocity). The advantage over a conical scan is a higher horizontal resolution of 150-400 m depending on aircraft speed and accumulation time. This is useful for the investigation of small-scale structures as, for example, convective cells (section 5).

\section{b. Model descriptions}

We used the nonhydrostatic LM (Doms and Schättler 1999) from the German Weather Service (DWD), and the nonhydrostatic Penn State-NCAR Mesoscale Model (Grell et al. 1995) for this research. Both were initialized at 0000 UTC on 19 July 2002. The LM was run with a horizontal mesh size of $7 \mathrm{~km}\left(0.0625^{\circ}\right)$ and $2.8 \mathrm{~km}\left(0.025^{\circ}\right)$. The model domain extended from $46.5^{\circ}$ to $49.5^{\circ} \mathrm{N}$, and from $9.3^{\circ}$ to $13.7^{\circ} \mathrm{E}$. The initial and boundary fields were provided every hour directly by the global-scale hydrostatic model of the DWD (GME; Majewski et al. 2002) forecast with $55 \mathrm{~km}\left(0.5^{\circ}\right)$ mesh size, applying an icosahedral-hexagonal grid and 31 vertical layers. The LM uses an Arakawa-C grid and has a generalized terrain-following vertical coordinate, which divides the model atmosphere into 40 layers from the earth's surface up to $20 \mathrm{hPa}$. The vertical resolution is highest close to the surface $(35 \mathrm{~m})$ and decreases with altitude. The prognostic model variables are the wind vector, temperature, pressure, specific humidity, and cloud liquid water. The time step is $8 \mathrm{~s}$. The model includes a grid-scale cloud and precipitation scheme as well as a parameterization of moist convection (Tiedtke 1989), which was switched off for the $2.8-\mathrm{km}$ run. The radiation scheme employs eight spectral intervals and is based on the solution of the two-stream version of the radiative transfer equation. Direct radiation interaction with cloud water and cloud ice is allowed for. Subgridscale cloudiness is diagnosed from relative humidity. The soil model has three layers for the water budget
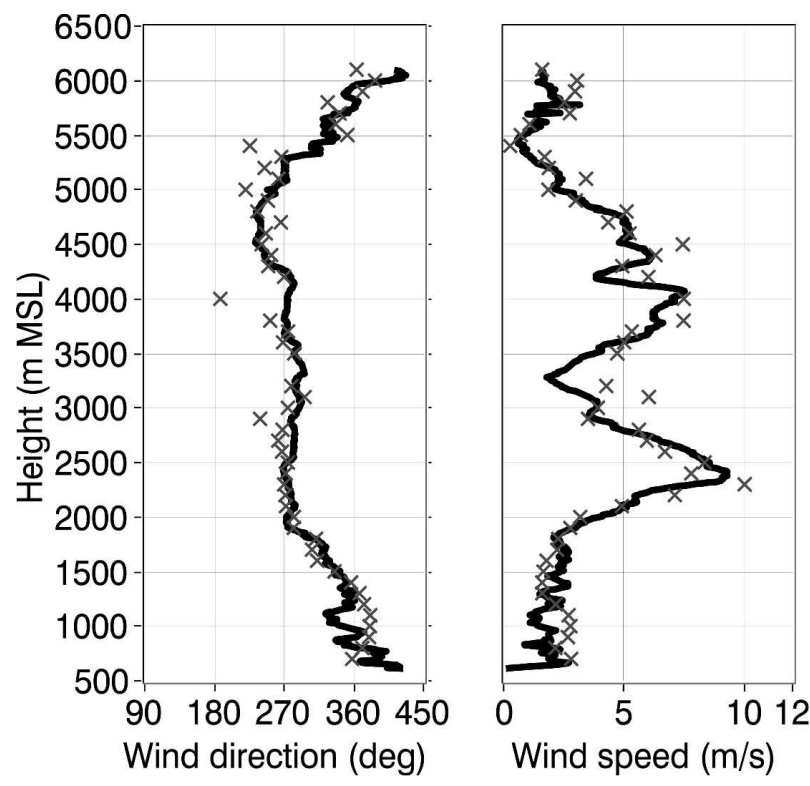

Fig. 2. Vertical profile of (left) wind direction and (right) wind speed at $47.94^{\circ} \mathrm{N}$ and $12.21^{\circ} \mathrm{E}$. Dropsonde data are shown with a black solid line and lidar data with gray $\times$. The lidar data were taken at 1616 UTC, and the dropsonde measurements between 1616 and 1624 UTC.

and two for the heat budget. The prognostic variables soil temperature and soil moisture are calculated with an extended force-restore method. In addition to its application for research purposes in regional weather and climate forecasting, LM with a mesh size of $7 \mathrm{~km}$ is used for operational weather forecasting in Germany, Greece, Poland, and Switzerland.

The MM5 was run using either two or three interactively nested grids: The coarse domain covered most of central Europe with a horizontal grid length of $18 \mathrm{~km}$ and $70 \times 70$ grid points, and the inner domain had a grid length of $6 \mathrm{~km}$ and $97 \times 106$ grid points (MM5 6-km run). Additionally, one simulation was made with a third domain with a grid length of $2 \mathrm{~km}$ and $97 \times 136$ grid points (MM5 2-km run). The initial and boundary conditions were taken from European Centre for Medium-Range Weather Forecasts (ECMWF) analyses with the boundary values updated every $6 \mathrm{~h}$. The model uses a terrain-following coordinate system with 38 layers up to the upper boundary at $100 \mathrm{hPa}$. The lowest level on which horizontal winds are calculated is about $25 \mathrm{~m}$ above the ground.

The Rapid Radiative Transfer Model (RRTM) longwave radiation scheme (Mlawer et al. 1997) was combined with the Dudhia shortwave scheme so that radiative effects due to clouds were included. In the 6- and 18-km domains the Grell scheme was used for parameterization of moist convection. In the $2-\mathrm{km}$ domain, 
the parameterization of moist convection was switched off. For the parameterization of the planetary boundary layer the Gayno-Seaman scheme was used (Gayno 1994). This parameterization is based on the MellorYamada turbulent kinetic energy (TKE) prediction and uses liquid-water potential temperature as a conserved variable. For explicit moisture the Reisner scheme was used (Reisner et al. 1998). A five-layer soil model with a fixed substrate below was used.

Additionally, sensitivity studies were performed with the MM5 6-km run to investigate the influence of the initial fields (ECMWF and GME), the domain size, the soil moisture, and different PBL schemes [MediumRange Forecast (MRF; Hong and Pan 1996) and Blackadar (Zhang and Anthes 1982)].

\section{Synoptic overview and temporal evolution}

The weather in the investigation area on 19 July 2002 was dominated by a high pressure system centered over the English Channel. This led to a fairly sunny day with weak pressure gradients and large-scale winds. At approximately half the height of the Alps $(850 \mathrm{hPa})$ the geopotential field over the investigation area was nearly uniform (Fig. 3). Maximum temperatures in the area were moderate $\left(20^{\circ}-25^{\circ} \mathrm{C}\right)$, and convection was limited to the formation of a few isolated cumulus clouds. An upper-level depression had passed the region on the previous day and had caused light rain (0-2 $\mathrm{mm})$. But the remaining clouds dissolved in the morning hours of 19 July. Another low pressure system was centered over the Baltic Sea. The advection of cool subpolar air on the back of this system caused fairly low maximum temperatures in the investigation area despite a sunshine duration of about $10 \mathrm{~h}$.

As described in section 1 the air in the Alpine valleys was heated faster than the air in the plains north of the Alps. At 1200 UTC the boundary layer at Innsbruck was $6 \mathrm{~K}$ warmer than the boundary layer at Munich (Fig. 4). Consequently, the pressure was higher in the plains than in the mountains. The pressure difference between Munich and Innsbruck was about $2.5 \mathrm{hPa}$. This pressure difference caused a well-pronounced flow from the foreland to the Alps (Alpine pumping) of $1-3 \mathrm{~m} \mathrm{~s}^{-1}$ in the lowest $1000 \mathrm{~m}$ of the boundary layer.

The time-height cross section of wind at Lichtenau, Germany (Fig. 5), gives a temporal overview of the evolution of Alpine pumping on 19 July. The measurements are located about $35 \mathrm{~km}$ north of the Alps (Fig. 1). Northerly flow at the ground began at about 0930 UTC ( 1015 local solar time). Alpine pumping started as a shallow layer close to the ground, which gradually

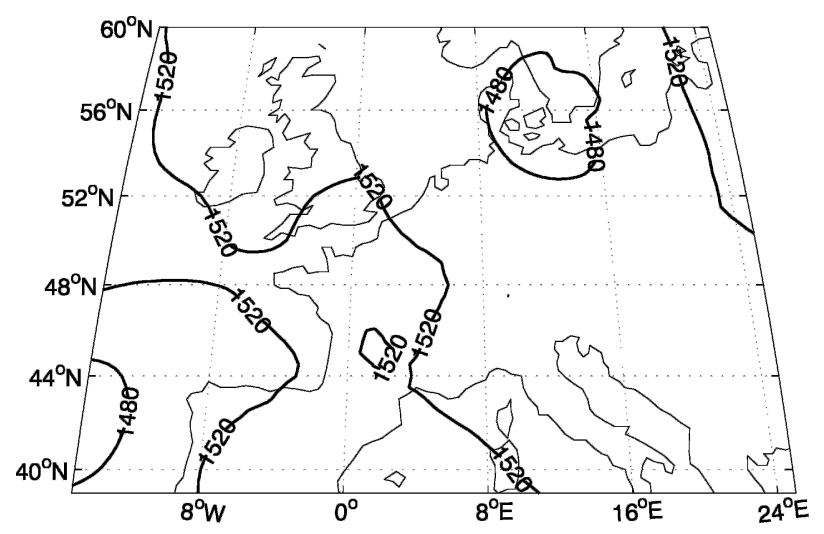

FIG. 3. ECMWF analysis of 850-hPa geopotential height (40-m interval) at 1200 UTC 19 Jul 2002 showing nearly uniform conditions in the larger investigation area (cf. Fig. 1).

increased in depth to about $1000 \mathrm{~m}$ in the afternoon. In the first few hours the wind direction and wind speed were quite variable, but then a fairly steady northerlynortheasterly flow developed in the afternoon. The following sections discuss the characteristics of Alpine pumping using measurements taken during this steady state in the afternoon. After sunset at 1900-1915 UTC (1945-2000 local solar time) the depth of the northerly flow decreased to about $500 \mathrm{~m}$. Finally, the decay of Alpine pumping was seen between 2000 and 2300 UTC (2045-2345 local solar time) as a turning to easterly winds, followed by southerly winds later in the night (not shown).

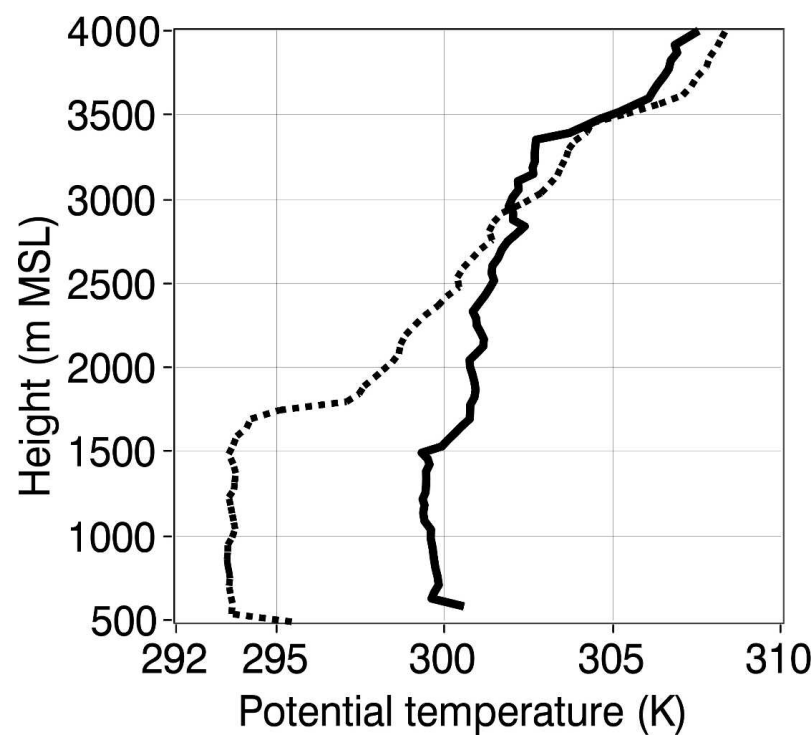

FIG. 4. Vertical profiles of potential temperature from rawinsondes at Munich (dotted line) and Innsbruck (solid line) at 1200 UTC 19 Jul 2002. 


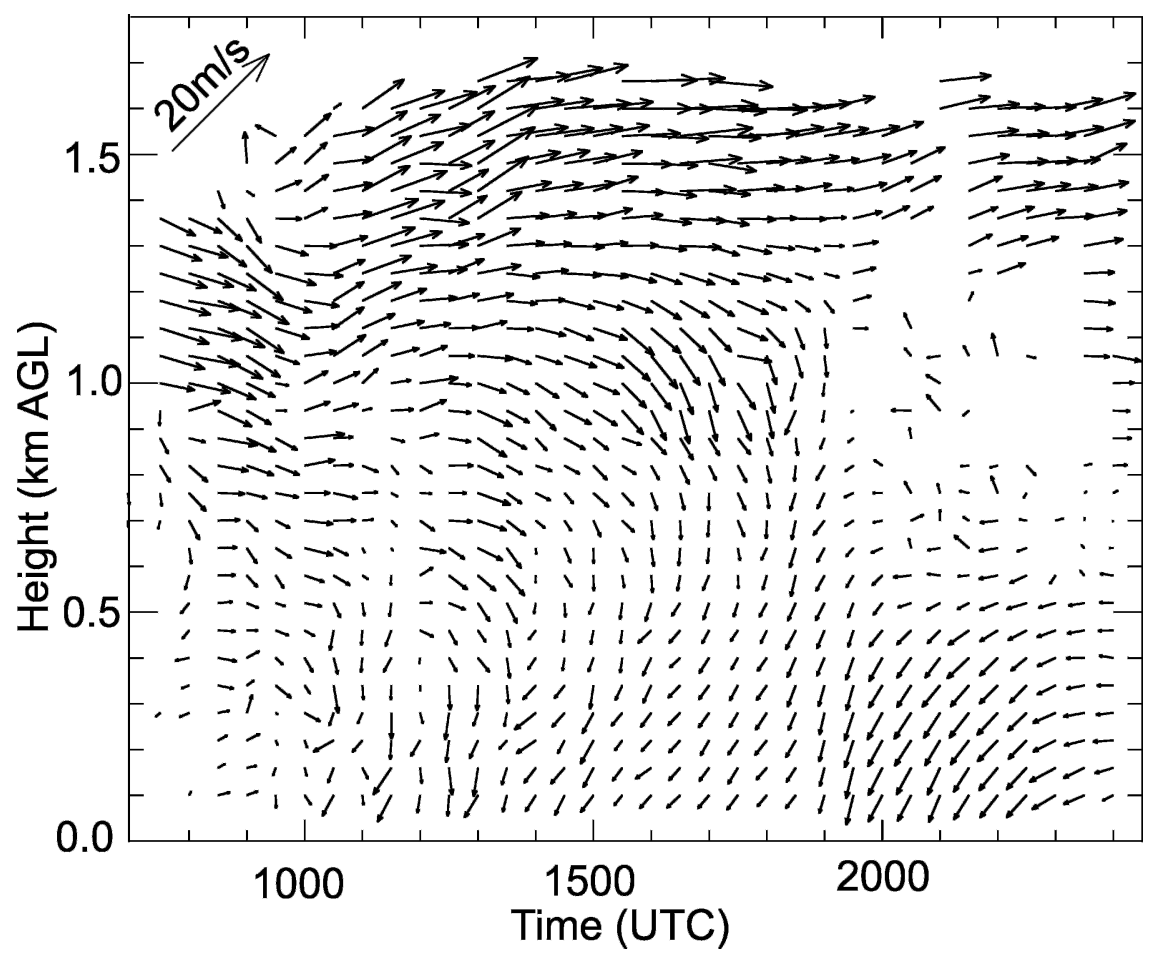

FIG. 5. Time-height cross section of wind measured with a wind-temperature radar at Lichtenau $\left(47.881^{\circ} \mathrm{N}, 11.225^{\circ} \mathrm{E}\right)$. The averaging time for each profile was $30 \mathrm{~min}$. The length of the arrows is proportional to the wind speeds. A reference arrow in the upper-left corner shows a southwesterly wind of $20 \mathrm{~m} \mathrm{~s}^{-1}$. (Courtesy of S. Vogt.)

\section{Structure of Alpine pumping}

A north-south cross section roughly perpendicular to the Alps illustrates the vertical structure of Alpine pumping (Fig. 6). This cross section is a combination of data from several remote and in situ sensors: the airborne Doppler lidar, one rawinsonde, one dropsonde, a wind-temperature radar, a ground-based aerosol lidar, and two pilot balloons. The measurements were taken between 1500 and 1700 UTC. Their locations are shown in Fig. 1. The upper boundary of northerly flow is indicated by horizontal bars. Different heights at the same latitude are caused by the different longitudinal location of the measurements, and a time difference of up to $2 \mathrm{~h}$. In general the different measurements are in good agreement.

The measurements show northerly flow with a horizontal extension of about $80 \mathrm{~km}$ (Figs. 4 and 6). The rawinsonde at Munich ( $\sim 80 \mathrm{~km}$ north of the Alps) and lidar profiles in this area were the northernmost wind profiles, which clearly showed Alpine pumping. Farther north some wind profiles also showed northerly wind components, but the flow was no longer a cohesive layer and it was very weak $\left(<1 \mathrm{~m} \mathrm{~s}^{-1}\right)$.

The layer with northerly flow was about $800 \mathrm{~m}$ in depth at Munich, but did not extend through the whole boundary layer. The depth increased gradually to the south by $400 \mathrm{~m}$ to about $1200 \mathrm{~m}$ at the northern rim of the Alps. The height of the boundary layer as represented by the elevated base of a temperature inversion and the aerosol signal increased about $300 \mathrm{~m}$ over the same distance. This rise is similar to the topography rise from north to south. Farther to the south, above the Alps, the aerosol boundary layer rose to $4200 \mathrm{~m}$ MSL, which is about $1500 \mathrm{~m}$ above the highest peaks in this part of the Alps. This was caused by stronger convection above the Alps and a net rise related to the stronger heating of air in Alpine valleys than over plains (section 1).

The wind speeds within the layer of Alpine pumping were generally low $\left(1-4 \mathrm{~m} \mathrm{~s}^{-1}\right)$ as shown in the westeast cross sections (Fig. 7). The wind direction was variable, especially on the southern cross section at the northern rim of the Alps (Fig. 7c). Nevertheless, both cross sections show a distinct mass flux toward the Alps up to about $1900 \mathrm{~m}$ MSL. As described in previous studies (e.g., Burger and Ekhart 1937), Alpine pumping is not a closed circulation as the return flow is usually masked by gradient winds. On 19 July 2002 the measurements showed westerly to southwesterly winds 


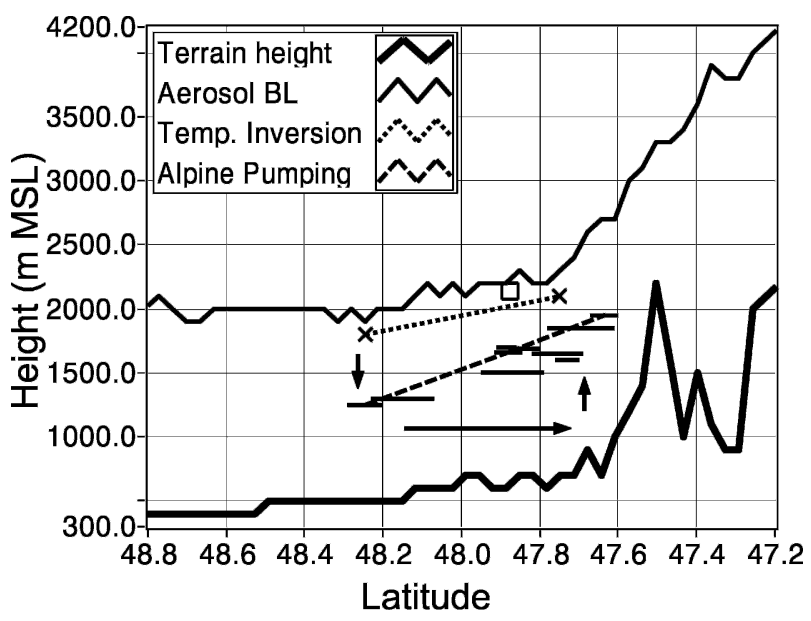

FIG. 6. Vertical cross section from (left) north to (right) south. The abscissa is the latitude $\left({ }^{\circ} \mathrm{N}\right)$, and the ordinate is the height $(\mathrm{m}$ MSL). A thick solid line shows the height of the terrain (ground return of lidar measurements); one square and a thin solid line show the height of the aerosol boundary layer (layer with strong lidar signal) measured with a ground-based backscatter lidar at Lichtenau $\left(47.881^{\circ} \mathrm{N}, 11.225^{\circ} \mathrm{E}\right)$ and the airborne Doppler lidar respectively; the height of the convective boundary layer (layer with constant potential temperature) derived from a rawinsonde at Munich and a dropsonde at $47.94^{\circ} \mathrm{N}$ and $12.21^{\circ} \mathrm{E}$ is shown with two $X$ 's. Horizontal bars show the upper boundary of northerly flow (Alpine pumping) derived from Doppler lidar data, a windtemperature radar, two pilot balloons, one rawinsonde, and one dropsonde. The measurements were taken between 1500 and 1700 UTC. The location of the measurements and the cross section $\left(\mathrm{CC}^{\prime}\right)$ is shown in Fig. 1.

above the boundary layer (2000-3000 m MSL; Fig. 7). This weak southerly wind component indicates a return flow. Wind speeds showed a distinct maximum in this layer of west-southwesterly flow (Figs. 1 and 5), which was not observed farther to the north. This wind maximum was also reproduced by numerical simulations with MM5 and LM. Based on these simulations (not shown) it was interpreted as result of a convergence in the north-south direction: The southerly return flow of Alpine pumping meets with a west-northwesterly largescale flow in this area. This caused an acceleration in the west-east direction.

Horizontal convergence is seen between the northerly and southerly cross sections in the Alpine foreland, and the lidar measured a net rise on these cross sections of $0.05-0.1 \mathrm{~m} \mathrm{~s}^{-1}$ as discussed in detail in section 5 . Farther north the lidar measured a horizontal divergence (not shown), and hence a net sinking is expected. This is also indicated by the numerical simulations (not shown). Two wind maxima were seen on the southern cross section (Fig. $7 \mathrm{~d}$ ) at $10.4^{\circ}$ and $11.7^{\circ}$ E. However, these wind maxima appear to be unrelated to the entry regions of larger valleys such as the Walsertal $\left(10.25^{\circ} \mathrm{E}\right)$, the Lechtal $\left(10.8^{\circ} \mathrm{E}\right)$, the Loisachtal $\left(11.2^{\circ} \mathrm{E}\right)$, the Isartal $\left(11.55^{\circ} \mathrm{E}\right)$, or the Inntal $\left(12^{\circ}-12.2^{\circ} \mathrm{E}\right)$.

As described in section 1, lidar data are continuous measurements along the flight track, which are then accumulated to wind profiles at $5-\mathrm{km}$ intervals. With these data it is possible to quantify the mass flux from the plains to the Alps with vertical cross sections of continuous measurements for the first time. The transport of air through the northern cross section was $4.96 \times 10^{8} \mathrm{~kg} \mathrm{~s}^{-1}$, and the transport through the southern one was $3.92 \times 10^{8} \mathrm{~kg} \mathrm{~s}^{-1}$. The lengths were 223 and $212 \mathrm{~km}$, respectively (Fig. 1). The mass flux was calculated up to a height of $1900 \mathrm{~m}$ MSL, where the upper boundary of Alpine pumping was found (Fig. 7). Missing values close to the ground (blank spots in Fig. 7) were extrapolated from wind measurements above. The density was calculated using pressure, temperature, and humidity from the five dropsondes.

The uncertainty of the observed mass flux was estimated with the assumption that the extrapolated wind components have a maximum bias of less than $50 \%$, and that the lidar measurements have a maximum bias of $0.1 \mathrm{~m} \mathrm{~s}^{-1}$. This results in an uncertainty of $\pm 18 \%$.

With the assumption that the time evolution of Alpine pumping at the wind-temperature radar at Lichtenau (Fig. 5) is representative for the whole cross section, this means that nearly the entire air layer in the lowest kilometer of the atmosphere between Munich ( $80 \mathrm{~km}$ north of the Alps) and the Alpine rim is transported to the Alps on a sunny day in summer.

\section{Evaluation of numerical simulations}

\section{a. Temperature and humidity}

Four numerical simulations were made to investigate the ability of mesoscale models to reproduce the thermally driven wind system of Alpine pumping: two simulations used MM5 (mesh size $=2$ and $6 \mathrm{~km}$ ) and two used LM (mesh size $=2.8$ and $7 \mathrm{~km}$ ). All simulations were able to reproduce the general temperature field on 19 July 2002, and the mean temperature differences between the simulations and the dropsonde measurements were less than $0.8 \mathrm{~K}$ within the boundary layer (Fig. 8).

The best agreement with dropsonde measurements was seen in the LM 7-km run, which showed average temperatures within the boundary layer $0.3 \mathrm{~K}$ lower than the average of the five dropsondes. The temperatures of the MM5 with 2-km mesh size and of the LM with $2.8-\mathrm{km}$ mesh size were $0.5 \mathrm{~K}$ too low. The largest difference was seen in the MM5 run with 6-km mesh size, which was $0.8 \mathrm{~K}$ too cold within the boundary layer. The temperature difference between simulations 
Wind direction (northern cross-section)

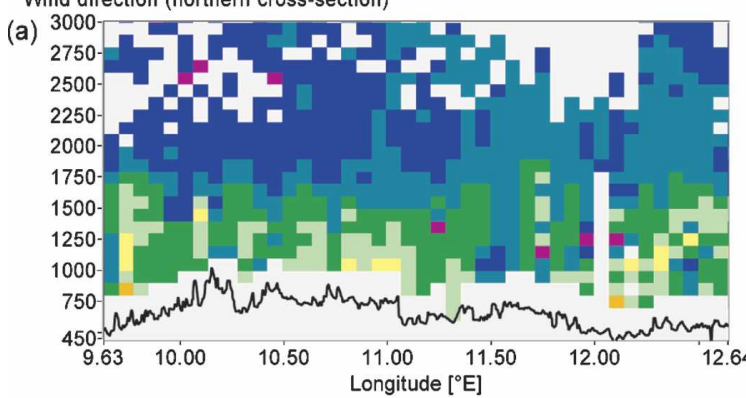

Wind speed (northern cross-section)

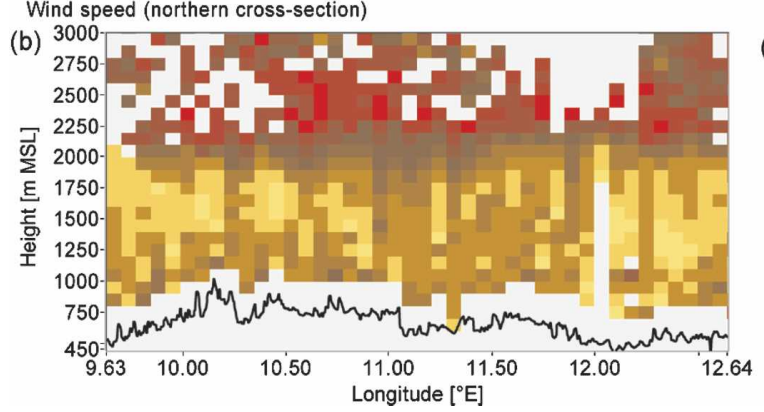

Wind direction (southern cross-section)

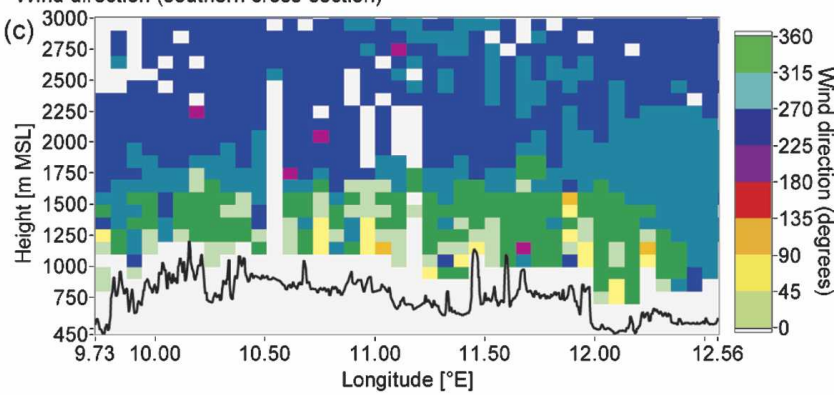

Wind speed (southern cross-section)

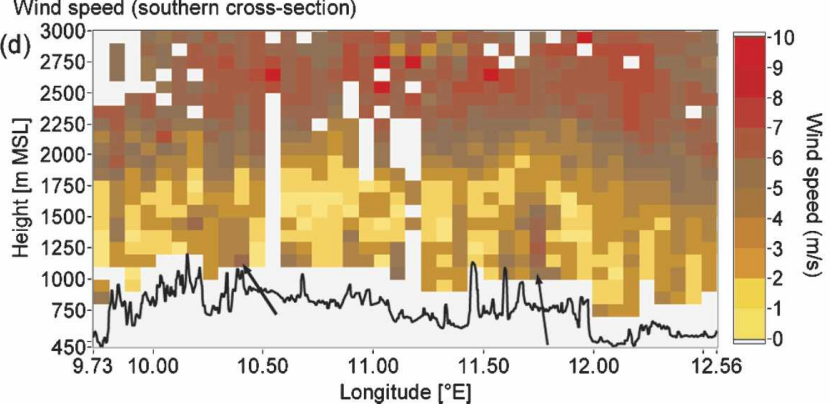

FIG. 7. West-east cross sections of (a), (c) wind direction and (b), (d) wind speed. A solid black line shows the height of the topography derived from the ground return of the lidar signal. The locations of the (a), (b) northern and (c), (d) southern cross sections are shown in Fig. 1 with the lines $\mathrm{AA}^{\prime}$ and $\mathrm{BB}^{\prime}$, respectively. The lengths of the cross sections are $223 \mathrm{~km}$ (northern cross section) and $212 \mathrm{~km}$ (southern cross section). Two wind maxima on the southern cross section are marked with arrows.

and dropsondes was mainly caused by the two northermost dropsondes, which were about $0.5-1 \mathrm{~K}$ too cold in the models, while the three southern dropsondes were simulated well by the models (not shown). The humidity in the boundary layer was generally too high in the simulations (Fig. 8): In the LM with 2.8-km mesh size it was $10 \%-20 \%$ too high, and in the other simulations $5 \%-10 \%$ too high. The difference of up to $20 \%$ between 1500 and $2000 \mathrm{~m}$ MSL was caused by the two western dropsondes. The convective boundary layer depths measured by these dropsondes was about $400 \mathrm{~m}$ less than in the simulations (not shown). We assume that the overestimation of humidity was mostly caused by an improper representation of the stabilizing effect of the Bodensee, a lake in the region where the two western dropsondes were launched (Fig. 1).
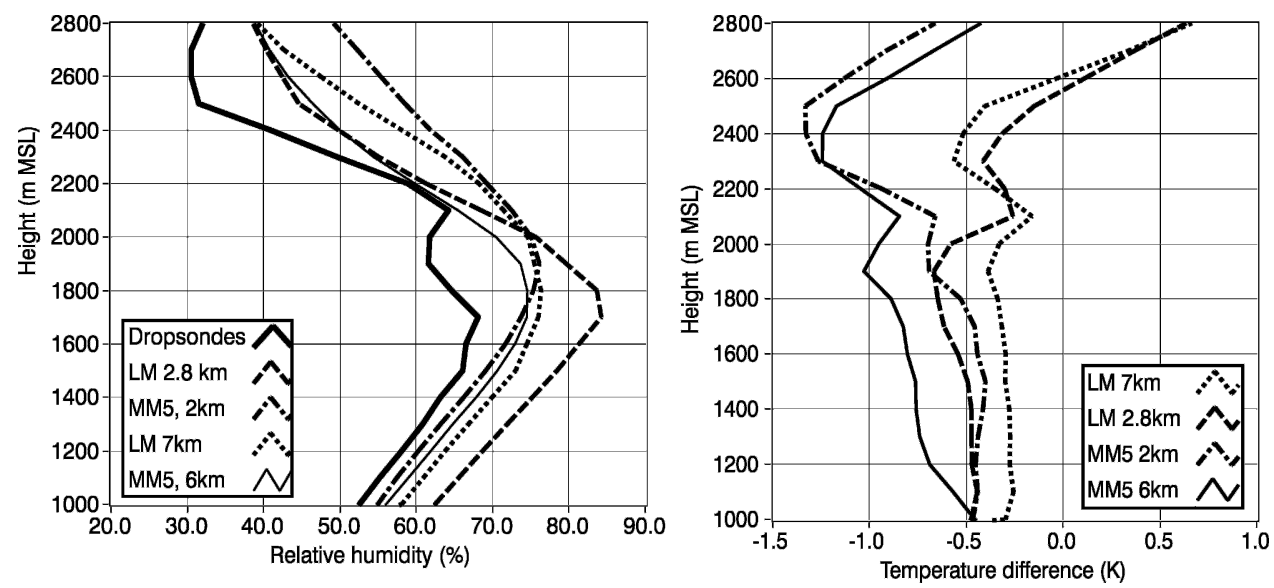

FIG. 8. (left) Mean profile of relative humidity averaged over five dropsondes and the corresponding profiles from LM and MM5. (right) Mean profile of the temperature difference between dropsondes and corresponding profiles from LM and MM5. The profiles from simulations were interpolated linearly to the dropsonde positions in time and space. 

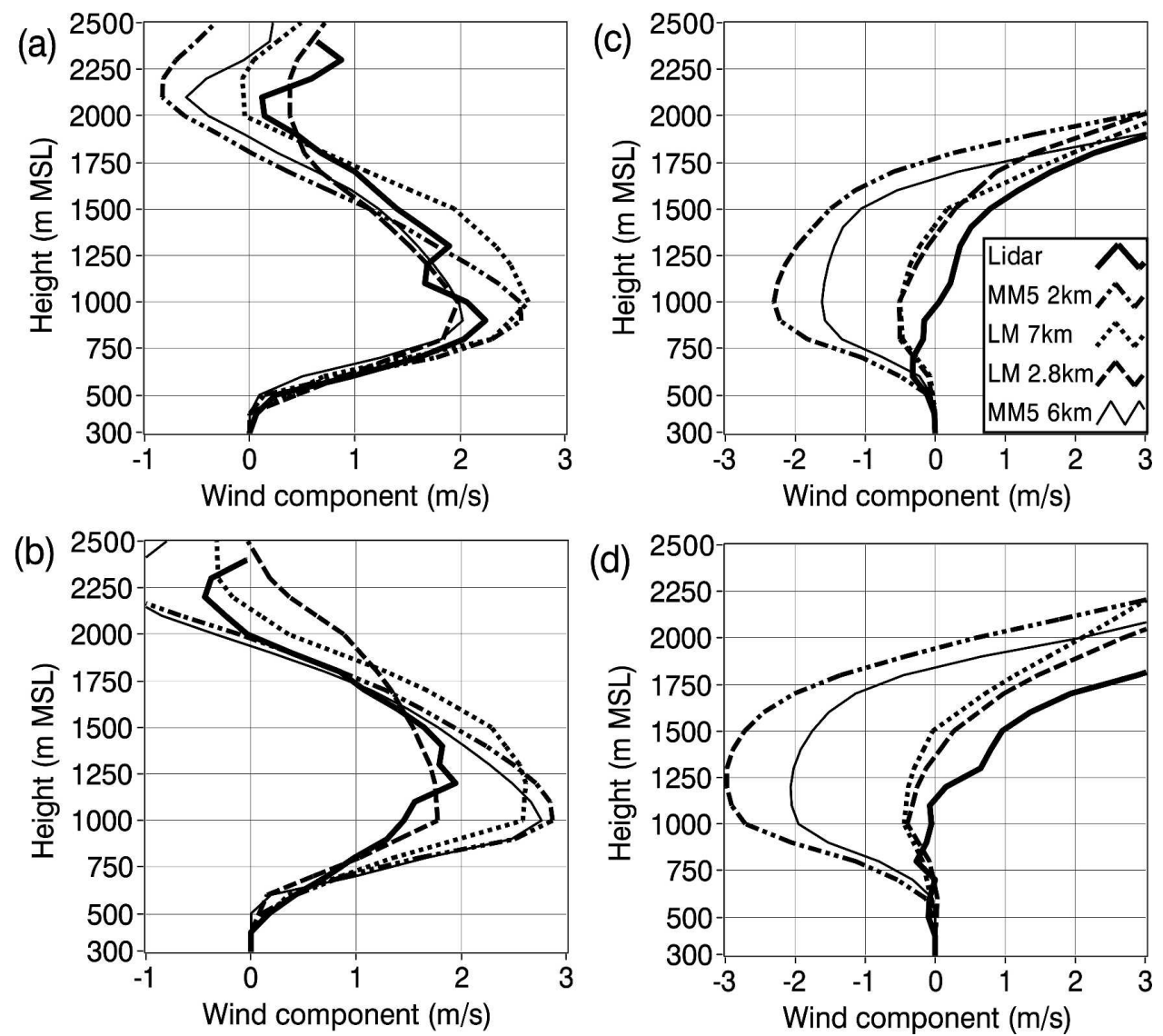

FIG. 9. Profiles of the wind components (a), (b) perpendicular and (c), (d) parallel to the flight track. Positive values are winds from $350^{\circ}$ (toward the Alps) in Figs. $8 \mathrm{a}$ and $8 \mathrm{~b}$, and winds from $80^{\circ}$ in Figs. $8 \mathrm{c}$ and $8 \mathrm{~d}$. Figures $8 \mathrm{a}$ and $8 \mathrm{c}$ are averaged along the northern west-east cross section (AA' in Fig. 1), and Figs. $8 \mathrm{~b}$ and $8 \mathrm{~d}$ along the southern west-east cross section (BB' in Fig. 1). Missing values were extrapolated from winds above. Values beneath the ground were set equal to zero.

Overall the temperature and humidity differences (0.3-0.8 K and $5 \%-20 \%$, respectively) are seen to be within an acceptable range (regarding the fact that there is an observational error, a representativeness error of the comparison, and an error of the analyses used to initialize the simulations).

\section{b. Wind field}

One intention of this study was to quantitatively evaluate the numerical simulation of the mass flux from the foreland to the Alps on summer days with high solar radiation. For this reason we calculated the wind component perpendicular to the two flight tracks along the northern rim of the Alps using data from the airborne Doppler lidar. Missing values close to the ground (white spots in Fig. 7) were extrapolated from winds above. These perpendicular wind components at $\sim 5$ $\mathrm{km}$ intervals were then averaged along the flight path to obtain mean wind profiles (Fig. 9). Similarly, the nu- merical simulations were interpolated to the positions of the lidar profiles, and then averaged horizontally to mean vertical profiles in the same way as the lidar data. The ratio of the mass flux determined from lidar data to the simulations is shown in Table 2. The uncertainty of the mass flux derived from lidar data was estimated to be less than $18 \%$ (section 3 ).

The profiles of the mean wind component perpendicular to the flight track (Figs. 9a and 9b) show that all simulations were generally able to reproduce the mass flux toward the Alps. Even the simulations with the coarse mesh of $6 \mathrm{~km}$ (MM5) and $7 \mathrm{~km}$ (LM) performed well. The simulated profiles for the northern flight leg agreed especially well with the measurements, and the simulated mass flux was within a range of $86 \%-122 \%$ of the measurements (nearly within the uncertainty of the observed mass flux). The largest discrepancy is seen in the LM 7-km run, which overestimated the mass flux by $22 \%$. In both MM5 runs the layer with northerly 
TABLE 2. Mass flux through the northern (North) and southern (South) vertical cross sections in relation to the mass flux derived from lidar data. The location of the cross section is shown in Fig. 1. The mass flux was calculated up to a height of $1900 \mathrm{~m}$ MSL.

\begin{tabular}{lcccc}
\hline \hline & MM5, 2 km & MM5, 6 km & LM, 2.8 km & LM, 7 km \\
\hline North & $100 \%$ & $86 \%$ & $89 \%$ & $122 \%$ \\
South & $143 \%$ & $133 \%$ & $101 \%$ & $144 \%$ \\
\hline
\end{tabular}

flow was slightly too shallow ( $\sim 200 \mathrm{~m}$ less than in the measurements). In the MM5 2-km run this was compensated by a stronger maximum and the mass flux agreed with the lidar. In the 6-km run the mass flux was $14 \%$ too low. On the southern cross section, all simulations except the LM $2.8-\mathrm{km}$ run overestimated the mass flux by $33 \%-44 \%$. Consequently, the convergence between the two cross sections (Fig. 10) was also too low in these simulations. Thus it was concluded that the rising motion in the models is spatially restricted too much to the Alps, while in reality smaller hills and valleys in the forelands also produce mean rising motions (section 5). The LM with a mesh size of $2.8 \mathrm{~km}$ simulated the mass flux through the southern cross section and the convergence between the cross sections best. But the boundary layer and the layer with northerly flow were about $300 \mathrm{~m}$ too deep in the simulation (Figs. $7 \mathrm{a}$ and $9 \mathrm{~b})$.

Overall the deviations of the simulated mass fluxes are within an acceptable range of the observations re-

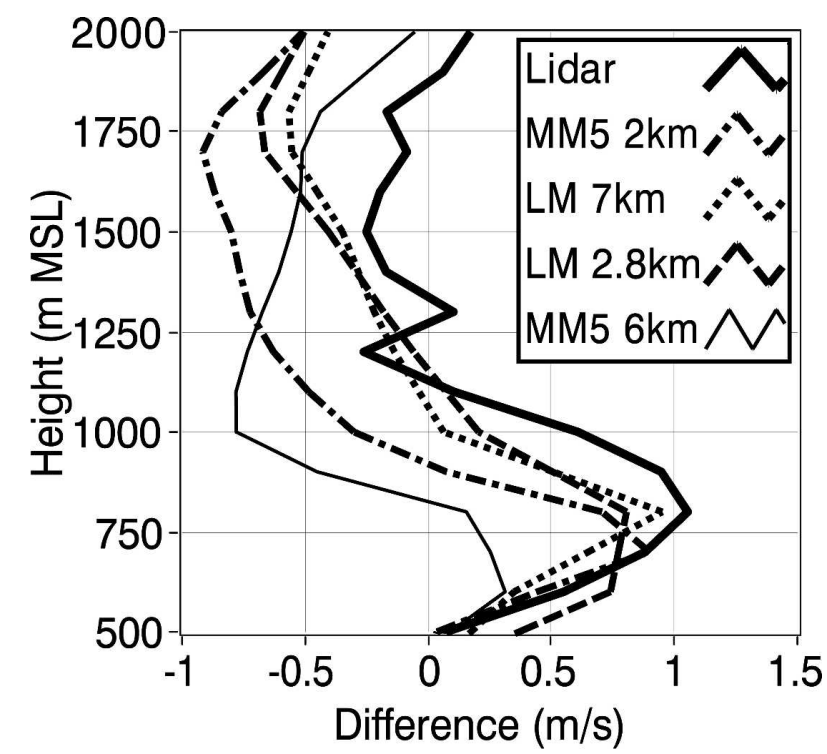

FIG. 10. Difference between the perpendicular wind components on the northern $\left(\mathrm{AA}^{\prime}\right)$ and southern $\left(\mathrm{BB}^{\prime}\right)$ flight track cross sections shown in Figs. 9a and 9b. Positive values indicate convergence. The distance between the two cross sections was about $15 \mathrm{~km}$. garding the weak intensity of the flow toward the Alps of only 1-3 $\mathrm{m} \mathrm{s}^{-1}$ (Fig. 9).

Despite the good representation of the mass flux through the cross sections, both MM5 simulations showed an along-track (easterly) wind component that was not seen in the measurements (Figs. 8c and 8d). The simulations of 8 July 2002, a day with a similar synoptic situation, also produced easterly wind components contradictory to the measurements of that day (not shown). In contrast the LM runs simulated the wind direction correctly and no significant along-track wind component was seen. Sensitivity studies with the MM5 model showed that this easterly wind component was much smaller if the Blackadar or the MRF PBL schemes (section 1) were used instead of the GaynoSeaman scheme (Fig. 11). However, the runs with the Blackadar and MRF PBL schemes both produced a PBL height that was a few hundred meters higher than in the measurements. This caused a thicker layer with flow toward the Alps (similar to the LM 2.8-km run). The velocity of the northerly flow was generally lower than in the MM5 run with the Gayno-Seaman PBL scheme. The total mass flux through the cross sections was about $10 \%-30 \%$ smaller in the MM5 runs with the Blackadar and MRF PBL schemes than with the GaynoSeaman scheme (because of a deeper PBL the mass flux was calculated up to $2300 \mathrm{~m}$ MSL for the comparison).

Another sensitivity experiment was performed to investigate how much of the difference between the MM5 and the LM simulations is due to the different initialization (and boundary) fields that were used for the simulations (ECMWF and GME). We conducted a MM5 6-km run with initial and boundary conditions from the GME model. However, the initial and boundary conditions are still not identical to that of the LM simulation because for the MM5 pressure level data are used whereas the LM uses a direct interpolation from GME model level data. Nevertheless, the experiment showed that the simulations are very sensitive to initialization field (Fig. 11). The MM5 simulation with the initial fields from the GME produced a larger mass flux toward the Alps (Alpine pumping), and generally had a larger PBL height. The easterly component was substantially reduced in these simulations.

These experiments documented the sensitivity of the simulations to the PBL scheme that is applied and the initialization fields. In contrast variations of the domain size or the soil moisture had little effect.

\section{Vertical motions}

The Doppler lidar also measured vertical velocities. In the scanning mode the measurements can be used to 

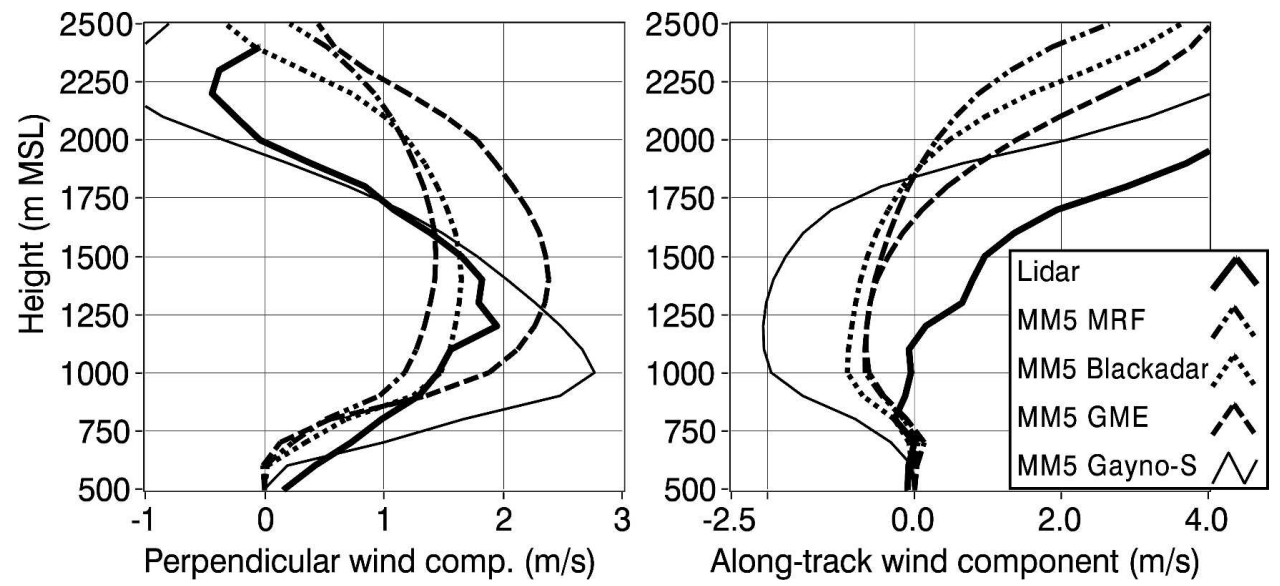

FIG. 11. Profiles of the wind component (left) perpendicular and (right) parallel to the flight track: (thick solid line) lidar measurements; (dashed-dotted) MM5 simulation with the MFR PBL scheme; (dashed) simulation with the Blackadar PBL scheme; (dotted) MM5 simulation with initial and boundary fields from GME; (thin solid line) MM5 simulation with the Gayno-Seaman PBL scheme (also shown in Figs. 8, 9, and 10). Positive values are winds from $350^{\circ}$ and $80^{\circ}$, respectively.

determine vertical profiles of the mean vertical velocity. The measured line-of-sight (LOS) velocity on a constant height level is approximately a sine wave. Looking into the wind the Doppler shift is positive, and looking in the opposite direction the shift is negative. An updraft in contrast is always positive. Hence the amplitude of the LOS velocity is proportional to the wind speed, the phase shift determines the wind direction, and the offset is proportional to the mean vertical velocity. In principle these profiles can be calculated for every scan revolution $(\sim 5 \mathrm{~km})$, but first they are often dominated by individual updrafts or downdrafts, and second the noise is quite large compared to the measured wind speeds. Therefore we calculated mean pro- files of the vertical velocity from about 40 scan revolutions on the southern and the northern west-east cross section in the Alpine foreland (Fig. 12). The accumulation algorithm (section 1a) was used for these profiles, because it is seen to be more precise for the calculation of profiles from several scan revolutions.

The magnitude of mean vertical velocities was only up to about $0.1 \mathrm{~m} \mathrm{~s}^{-1}$, which is challenging to resolve with an airborne Doppler lidar. However, the aircraft speed and attitude angles can be corrected with return from the nonmoving ground, which should have a zero velocity. After this correction the mean vertical velocity of the ground return was $-2 \times 10^{-3} \mathrm{~m} \mathrm{~s}^{-1}$ on the southern flight track and $-7 \times 10^{-3} \mathrm{~m} \mathrm{~s}^{-1}$ on the northern
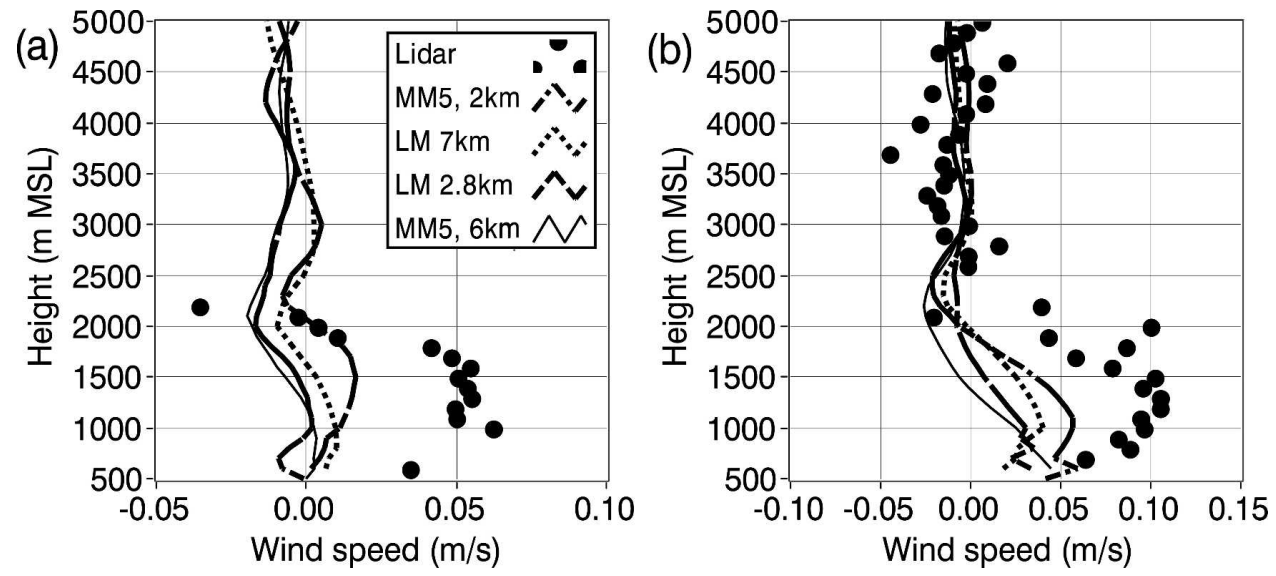

FIG. 12. Profiles of the mean vertical velocity averaged along (a) the northern cross section ( $\mathrm{AA}^{\prime}$ in Fig. 1), and (b) the southern west-east cross section (BB' in Fig. 1). The length of both cross sections used for the calculation was about $200 \mathrm{~km}$, respectively. 


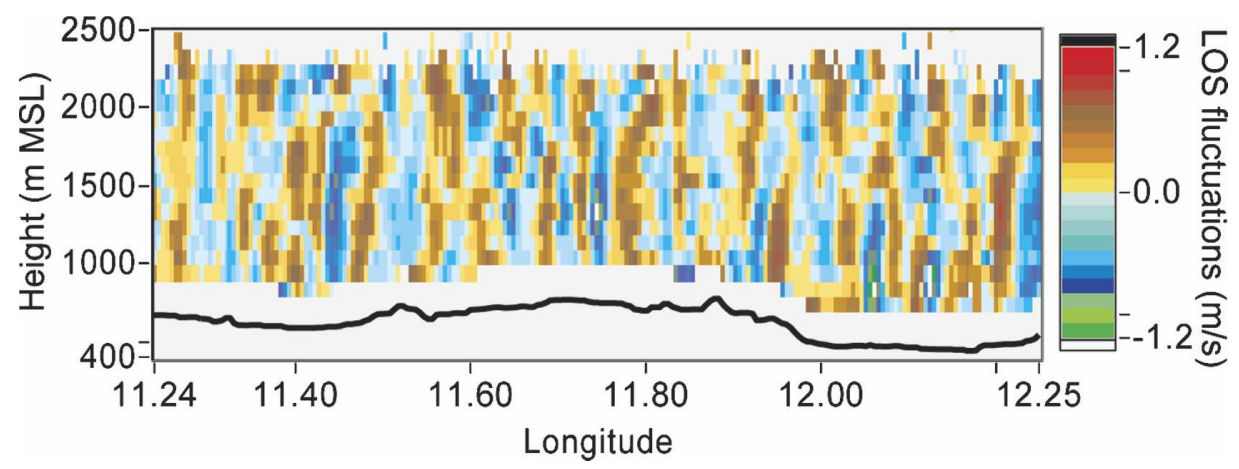

FIG. 13. Cross section of the fluctuations in the line-of-sight velocity on a scan with a constant viewing angle $\left(20^{\circ}\right.$ from nadir, azimuth $\left.=335^{\circ}\right)$. The basis of the cross section is the eastern part of the southern west-east cross section (BB') shown in Fig. 1. A solid black line shows the height of the topography derived from the lidar ground return.

one. Furthermore, the vertical velocities above the boundary layer, which should be close to zero in the present synoptic situation, can be used as a quality control for the lidar data.

The profiles (Fig. 12) show vertical velocities of up to $0.05 \mathrm{~m} \mathrm{~s}^{-1}$ on the northern flight track, and $0.1 \mathrm{~m} \mathrm{~s}^{-1}$ on the southern flight track. According to this mean rise a horizontal convergence was measured in between the two cross sections (Fig. 10). The measured convergence would result in a mean rise of about $0.04 \mathrm{~m} \mathrm{~s}^{-1}$ over the whole area using the continuity equation. However, the measurements on the northern cross section were taken nearly $1 \mathrm{~h}$ after those on the southern cross section, and the simulations indicate a weakening of Alpine pumping during that time. Thus the real convergence may have been higher, which could explain the measured vertical velocities. The structure of the vertical velocity profiles from the simulations is similar to the measurements, and the simulations also show an increase of the mean rising motions from north to south. The vertical velocities are generally lower in the simulations. Accordingly, the convergence between the two cross sections (Fig. 10) was lower in the simulations. It was concluded that the rising motion in the models is too much limited to mountain areas, whereas in reality stronger rising motions also occur in the Alpine foreland. Presumably, the underestimation of temperatures in the simulations (section 4a) is also caused by the differences in vertical velocities. The reason for this could be that the topography in the forelands with small hills and valleys is not completely resolved by the models.

However, it must be noted that the mean vertical velocity in the simulations is influenced by individual updrafts and downdrafts a lot more than the measurements, because the width of convection is too large in the simulations. The mean convective scale (width of one updraft and one downdraft) was about $27 \mathrm{~km}$ in the
MM5 2-km run, $31 \mathrm{~km}$ in the LM 2.8-km run, $45 \mathrm{~km}$ in the MM5 6-km run, and $60 \mathrm{~km}$ in the LM 7-km run. This means that the convective scale is about 10 times the mesh size. In contrast the convective scale in the measurements was only about $3 \mathrm{~km}$ (Figs. 12 and 13). Thus a further significant reduction of the mesh size would be necessary to resolve individual updrafts and downdrafts in numerical simulations (approximately a mesh size of 200-300 m or less).

In the lidar mode with a fixed viewing angle the fluctuations of the LOS velocity show the structures of convection (Fig. 13). A horizontal average over $18 \mathrm{~km}$ was subtracted from every range gate wind component (high-pass filter) to eliminate the mean horizontal wind and its mesoscale fluctuations, and a horizontal moving average over three LOS measurements $(1080 \mathrm{~m})$ was applied. The resulting fluctuations illustrate convective velocity fluctuations in the ABL. Similar fluctuations were documented by Couvreux et al. (2005) using an airborne water vapor lidar, in situ measurements of the vertical velocity, and large eddy simulations (LESs).

The LOS velocity at a nadir angle of $20^{\circ}$ consists of the vertical velocity multiplied with the cosine of $20^{\circ}$ (0.94), and the horizontal velocity multiplied with the sine of $20^{\circ}(0.34)$. Thus mainly fluctuations of the vertical velocity are measured, but also fluctuations of the horizontal wind contribute to a smaller extent.

One section of this data is shown in Fig. 13 (about $40 \%$ of the length of the measurements), and a histogram of these LOS velocities is shown in Fig. 14. The variance and the power spectrum in Fig. 14 were calculated from the LOS velocities without horizontal averaging and without filtering.

Figure 13 shows updrafts and downdrafts with a convective scale of about $3 \mathrm{~km}$. The maximum in the power spectrum (Fig. 14) was seen at wavelengths between 2.5 and $4 \mathrm{~km}$. At wavelengths of $0.7-2.5 \mathrm{~km}$ the power 

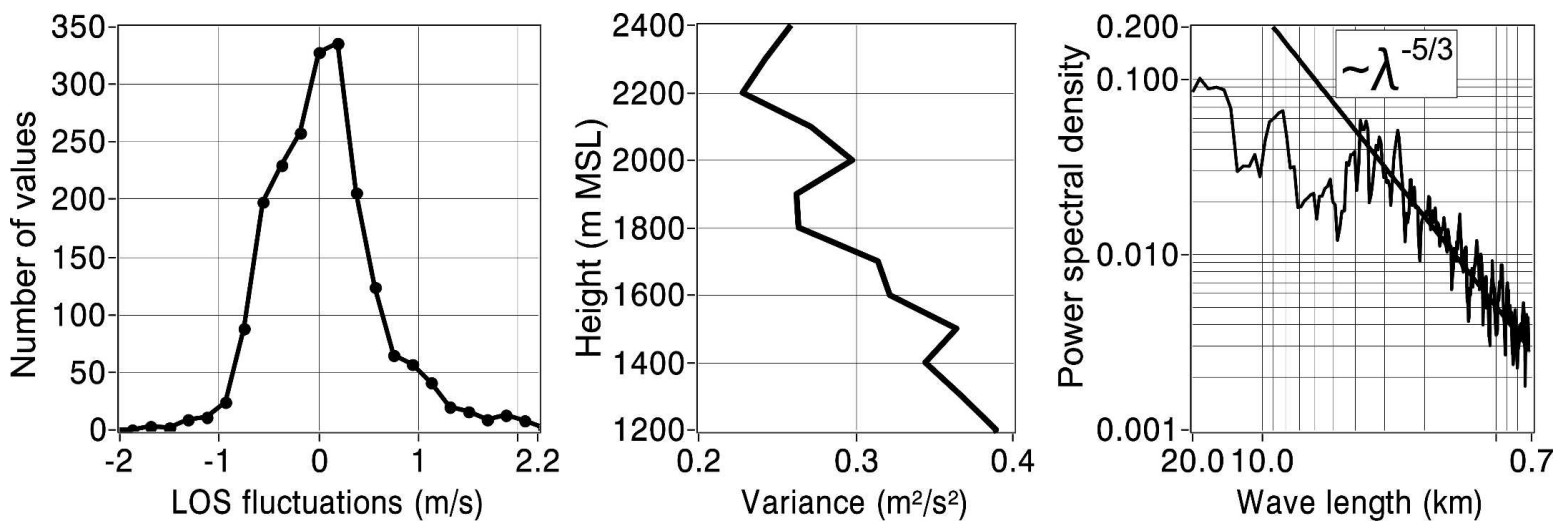

FIG. 14. (left) Histogram of the fluctuations of the LOS velocity between 1400 and $1700 \mathrm{~m}$ MSL derived from Doppler lidar measurements at a constant viewing angle. (middle) Variance of the LOS velocity. (right) Accumulated power spectrum of the LOS velocity at 1800, 1900, and $2000 \mathrm{~m}$ MSL. The location of the lidar measurements is the southern cross section in the Alpine foreland $\left(\mathrm{BB}^{\prime}\right)$ shown in Fig. 1; the length of the cross section was $212 \mathrm{~km}$.

spectrum shows a decrease with a $-5 / 3$ slope in agreement with the similarity theory for the inertial subrange of the turbulence power spectrum. A gap in the spectrum at wavelengths of 5-7 km divides mesoscale fluctuations with longer wavelengths from convection. The convective scale described in the literature (e.g., Young 1988 ) is about 1.5 times the depth of the CBL, which would only be about $2.25 \mathrm{~km}$ in this case. However, in contrast to most other studies the measurements on 19 July 2002 were taken in fairly complex terrain in the vicinity of the Alps. The mean vertical velocity (Fig. 12) was not equal to zero as it is usually assumed in largeeddy simulations. Furthermore, a small contribution of fluctuations of the horizontal velocity was also measured.

The backscatter intensity showed bulges of the upper boundary of the aerosol layer, and sometimes small cumulus clouds at the location of the updrafts (not shown), as it was also observed with ground-based Doppler lidar measurements (Giez et al. 1999; Cohn et al. 1998). The measurements were taken in the late afternoon (1537-1544 UTC), and the strength of the convective fluctuations was moderate. Figure 13 shows velocities up to $1.2 \mathrm{~m} \mathrm{~s}^{-1}$. Without the horizontal averaging, the velocities were up to $2.2 \mathrm{~m} \mathrm{~s}^{-1}$ as shown in the histogram. The variance of the vertical velocity decreased with height from about $0.4 \mathrm{~m}^{-2} \mathrm{~s}^{-2}$ at $1200 \mathrm{~m}$ MSL to $0.25 \mathrm{~m}^{-2} \mathrm{~s}^{-2}$ at $2200 \mathrm{~m}$ MSL. The histogram of the vertical velocity shows a slight skewness (Fig. 14): there are more downdrafts with a velocity of $0.3-0.9$ $\mathrm{m} \mathrm{s}^{-1}$ than updrafts of the same magnitude, and vice versa there are more updrafts with a velocity of $0.9-2.2$ $\mathrm{m} \mathrm{s}^{-1}$ than downdrafts. However, the asymmetry of updrafts and downdrafts was smaller than in other studies (Caughey and Palmer 1979; Willis and Deardorff 1974; Deardorff and Willis 1985).

\section{Conclusions}

The structure of the Alpine mountain-plain circulation (Alpine pumping) on 19 July 2002 was characterized with a variety of different instruments. The synoptic conditions in the investigation area were fairly typical: a high pressure system, weak pressure gradients, and high solar radiation. Consequently, a flow from the foreland to the Alps developed in the late morning hours, which evolved to a steady northerly flow in the afternoon. The layer with northerly flow extended about $80 \mathrm{~km}$ into the Alpine foreland. The depth of the layer increased from $800 \mathrm{~m}$ to the north to $1200 \mathrm{~m}$ at the rim of the Alps.

The mass flux from the foreland to the Alps could be determined with Doppler lidar measurements along two vertical cross sections parallel to the northern rim of the Alps. This was the first time that the mass flux could be quantified with continuous wind measurements. The mass flux through the northern cross section (length $=223 \mathrm{~km}$ ) was $5 \times 10^{8} \mathrm{~kg} \mathrm{~s}^{-1}$, and the flux through the southern one (length $=212 \mathrm{~km}$ ) was $3.9 \times$ $10^{9} \mathrm{~kg} \mathrm{~s}^{-1}$. On a sunny day in summer nearly the entire layer of air in the lowest kilometer of the atmosphere between Munich ( $\sim 80 \mathrm{~km}$ north of the Alps) and the Alps is transported to the Alps.

The measurements were used to test the ability of numerical models to reproduce the Alpine mountainplain circulation. The observed mass flux was compared to numerical simulations using the LM (mesh size 2.8 and $7 \mathrm{~km}$ ) and MM5 (mesh size 2 and $6 \mathrm{~km}$ ) models. All simulations were able to produce the mass flux toward the Alps within $86 \%-144 \%$ of the observations. Regarding the weak magnitude of the flow, the accuracy of the mean wind component toward the Alps was better 
than $1 \mathrm{~m} \mathrm{~s}^{-1}$. Even the two model runs with the coarse mesh of 6 and $7 \mathrm{~km}$ generally reproduced the mass flux although individual Alpine valleys cannot be resolved in these simulations.

The Doppler lidar also measures vertical velocity, and it was possible to calculate a mean profile of vertical velocity for every cross section. The mean velocities are only up to $0.1 \mathrm{~m} \mathrm{~s}^{-1}$, which is challenging to resolve with airborne Doppler lidar measurements. However, the aircraft attitude angles and speed were corrected with the speed of the ground return. After this correction the mean vertical velocity of the ground return was smaller than $0.01 \mathrm{~m} \mathrm{~s}^{-1}$. Furthermore, the structure of the profiles is similar in the measurements and the simulations, and the vertical velocity above the boundary layer is close to zero as it is expected for the synoptic situation on 19 July 2002. It was concluded that it is possible to measure mean vertical velocities with an airborne scanning Doppler lidar. Of course the measurements must be treated with caution, but not many other instruments are able to measure mean profiles of the vertical velocities with an accuracy better than $0.1 \mathrm{~m} \mathrm{~s}^{-1}$. Thus it seems this new method deserves further attention.

The fluctuations on a vertical cross section measured with the lidar at a constant viewing angle illustrate the structures of convection. The convective scale was about $3 \mathrm{~km}$ (two times the depth of the CBL), the strength of the fluctuations was up to $2.2 \mathrm{~m} \mathrm{~s}^{-1}$, the variance $0.25-0.4 \mathrm{~m}^{2} \mathrm{~s}^{-2}$, and the histogram showed a slight skewness. In contrast the convective scale in the simulations was approximately 10 times their mesh size, and it was concluded that a mesh size of 200-300 m or less would be necessary to resolve individual convective updrafts and downdrafts.

Acknowledgments. The authors want to thank several people who contributed to data to this study: Siegfried Vogt (IMK) provided the wind-temperature-radar data, Matthias Lugauer helped with rawinsonde and pilot balloon data, and Birgit Heese (University $\mathrm{Mu}-$ nich) supplied data from a ground-based aerosol lidar. Further thanks are due to Hans Volkert and Christoph Kiemle (both DLR), who supported the work with fruitful discussions, and to Dave Whiteman, who contributed several suggestions concerning the language and the content of the paper. The VERTIKATOR project was funded by the German "Bundesministerium für Bildung und Forschung" in the framework of the AFO2000 program.

\section{REFERENCES}

Banta, R. M., 1984: Daytime boundary-layer evolution over mountainous terrain. Part 1: Observations of the dry circulations. Mon. Wea. Rev., 112, 340-356.
- and C. B. Schaaf, 1987: Thunderstorm genesis zones in the Colorado Rocky Mountains as determined by traceback of geosynchronous satellite images. Mon. Wea. Rev., 115, 463476.

Bastin, S., P. Drobinski, A. Dabas, P. Delville, O. Reitebuch, and C. Werner, 2005: Impact of the Rhône and Durance Valleys on sea-breeze circulation in the Marseille area. Atmos. Res., 74, 308-328.

Burger, A., and E. Ekhart, 1937: Über die tägliche Zirkulation im Bereiche der Alpen. Gerl. Beitr. Geophys., 49, 341-367.

Browning, K. A., and R. Wexler, 1968: The determination of kinematic properties of a wind field using Doppler radar. $J$. Appl. Meteor., 7, 105-113.

Carnuth, W., and T. Trickl, 2000: Transport studies with the IFU three-wavelength aerosol lidar during the VOTALP Mesolcina experiment. Atmos. Environ., 34, 1425-1434.

Caughey, S. J., and S. G. Palmer, 1979: Some aspects of turbulence structure through the depth of the convective boundary layer. Quart. J. Roy. Meteor. Soc., 105, 811-827.

Cohn, S. A., S. D. Mayor, C. J. Grund, T. M. Weckwerth, and C. Senff, 1998: The Lidars in Flat Terrain (LIFT) Experiment. Bull. Amer. Meteor. Soc., 79, 1329-1343.

Corsmeier, U., C. Kottmeier, P. Winkler, M. Lugauer, O. Reitebuch, and P. Drobinski, 2003: Flow modification and mesoscale transport caused by Alpine Pumping: A VERTIKATOR case study. Proc. Int. Conf. on Alpine Meteorology, Brig, Switzerland, 138-140.

Cotton, W. R., R. L. George, P. J. Wetzel, and R. L. McAnelly, 1983: A long-lived mesoscale convective complex. Part I: The mountain-generated component. Mon. Wea. Rev., 111, 18931918.

Couvreux, F., F. Guichard, J.-L. Redelsperger, C. Flamant, V. Masson, C. Kiemle, and J.-P. Lafore, 2005: Water vapor variability within a convective boundary layer assessed by large eddy simulations and IHOP observations. Quart. J. Roy. Meteor. Soc., in press.

Deardorff, J. W., and G. E. Willis, 1985: Further results from a laboratory model of the convective planetary boundary layer. Bound.-Layer Meteor., 32, 205-236.

Doms, G., and U. Schättler, 1999: The nonhydrostatic limitedarea model LM (Lokal-Modell) of DWD. Part I: Scientific documentation. Research Department, German Weather Service, Offenbach, Germany, $160 \mathrm{pp}$.

Egger, J., 1987: Valley winds and the diurnal circulation over plateaus. Mon. Wea. Rev., 115, 2177-2186.

-, S. Bajrachaya, U. Egger, R. Heinrich, J. Reuder, P. Shayka, H. Wendt, and V. Wirth, 2000: Diurnal winds in the Himalayan Kali Gandaki valley. Part I: Observations. Mon. Wea. Rev., 128, 1106-1122.

Gayno, G. A., 1994: Development of a higher-order, fogproducing boundary layer model suitable for use in numerical weather prediction. M.S. thesis, The Pennsylvania State University, $104 \mathrm{pp}$.

Giez, A., G. Ehret, R. Schwiesow, K. J. Davis, and D. H. Lenschow, 1999: Water vapor flux measurements from groundbased vertically pointed water vapor differential absorption and Doppler lidars. J. Atmos. Oceanic Technol., 16, 237-250.

Grell, G. A., J. Dudhia, and D. R. Stauffer, 1995: A description of the fifth-generation Penn State/NCAR Mesoscale Model (MM5). NCAR Tech. Note TN-398+STR, 122 pp.

Hong, S.-H., and H.-L. Pan, 1996: Nonlocal boundary layer vertical diffusion in a medium-range forecast model. Mon. Wea. Rev., 124, 2322-2339. 
Lugauer, M., and P. Winkler, cited 2002: Untersuchungen zur thermischen Zirkulation zwischen Alpen und bayrischem Voralpengebiet. FE-Bericht of the German Weather Service (DWD). [Available online at http://www.dwd.de/de/FundE/ Veroeffentlichung/Ergebnisse/Ergebnisse.htm.]

— , and Coauthors, 2003: An overview of the VERTIKATOR project and results of Alpine Pumping. Proc. Int. Conf. on Alpine Meteorology, Brig, Switzerland, 129-132.

Majewski, D., and Coauthors, 2002: The operational global icosahedral-hexagonal gridpoint model GME: Description and high-resolution tests. Mon. Wea. Rev., 130, 319-338.

Mlawer, E. J., S. J. Taubman, P. D. Brown, and M. J. Iacono, 1997: Radiative transfer for inhomogeneous atmospheres: RRTM, a validated correlated-k model for the longwave. $J$. Geophys. Res., 102, 16 663-16 682.

Nyeki, S., and Coauthors, 2002: Airborne lidar and in-situ aerosol observations of an elevated layer, leeward of the European Alps and Apennines. Geophys. Res. Lett., 29, 1852, doi:10.1029/2002GL014897.

Rahm, S., R. Simmet, and M. Wirth, 2003: Airborne two micron coherent lidar wind profiles. Proc. 12th Coherent Laser Radar Conf., Bar Harbor, ME, 94-97.

Raymond, D., and M. Wilkening, 1980: Mountain-induced convection under fair weather conditions. J. Atmos. Sci., 37, 2693-2706.

Reisner, J., R. J. Rasmussen, and R. T. Bruintjes, 1998: Explicit forecasting of supercooled liquid water in winter storms using the MM5 mesoscale model. Quart. J. Roy. Meteor. Soc., 124B, 1071-1107.

Reitebuch, O., C. Werner, I. Leike, P. Deville, P. Flamant, A. Cress, and D. Engelbart, 2001: Experimental validation of wind profiling performed by the airborne $10-\mu \mathrm{m}$ heterodyne Doppler lidar WIND. J. Atmos. Oceanic Technol., 18, 13311344.

— , H. Volkert, C. Werner, A. Dabas, P. Delville, P. Drobinski, P. H. Flamant, and E. Richard, 2003: Determination of air flow across the Alpine ridge by a combination of airborne Doppler lidar, routine radio-sounding, and numerical simulation. Quart. J. Roy. Meteor. Soc., 129, 715-728.

— A. Dabas, P. Delville, P. Drobinski, L. Gantner, S. Rahm, and M. Weissmann, 2004: The Alpine mountain-plain circu- lation "Alpine Pumping": Airborne Doppler lidar observations at $2 \mu \mathrm{m}$ and $10.6 \mu \mathrm{m}$ and MM5 simulations. Proc. $22 d$ Int. Laser Radar Conf. (ILRC), Matera City, Italy, ESA SP561, 747-750.

Reiter, E. R., and M. Tang, 1984: Plateau effects on diurnal circulation patterns. Mon. Wea. Rev., 112, 638-651.

Schaaf, C. B., J. Wurman, and R. M. Banta, 1988: Thunderstormproducing terrain features. Bull. Amer. Meteor. Soc., 69, 272 277.

Seibert, P., H. Kromp-Kolb, A. Kasper, M. Kalina, H. Puxbaum, D. T. Jost, M. Schwikowski, and U. Baltensperger, 1998: Transport of polluted boundary layer air from the Po Valley to high-Alpine sites. Atmos. Environ., 32, 4075-4085.

Smalikho, I., 2003: Techniques of wind vector estimation from data measured with a scanning coherent Doppler lidar. $J$. Atmos. Oceanic Technol., 20, 276-291.

Steinacker, R., 1984: Area-height distribution of a valley and its relation to the valley wind. Beitr. Phys. Atmos., 57, 64-71.

Tiedtke, M., 1989: A comprehensive mass flux scheme for cumulus parameterization in large-scale models. Mon. Wea. Rev., 117, 1779-1800.

Vergeiner, I., and E. Dreiseitl, 1987: Valley winds and slope winds-Observations and elementary thoughts. Meteor. Atmos. Phys., 36, 264-286.

Whiteman, C. D., and X. Bian, 1998: Use of radar profiler data to investigate large-scale thermally driven flows into the Rocky Mountains. Proc. Fourth Int. Symp. on Tropospheric Profiling: Needs and Technologies, Snowmass, CO, Radian International Electronic Systems, 329-331.

Willis, G. E., and J. W. Deardorff, 1974: A laboratory model of the unstable planetary boundary layer. J. Atmos. Sci., 31, 1297-1307.

Wotawa, G., H. Kröger, and A. Stohl, 2000: Transport of ozone towards the Alps-Results from trajectory analyses and photochemical model studies. Atmos. Environ., 34, 1367-1377.

Young, G. S., 1988: Turbulence structure of the convective boundary layer. Part II: Phoenix 78 aircraft observations of thermals and their environment. J. Atmos. Sci., 45, 727-735.

Zhang, D.-L., and R. A. Anthes, 1982: A high-resolution model of the planetary boundary layer-Sensitivity tests and comparisons with SESAME-79 data. J. Appl. Meteor., 21, 1594-1609. 